\title{
Psychological predictors of inhibition development in educational environments
}

\author{
Elvira E. Symanyuk, Anna A. Pecherkina* \\ Department of Psychology, Ural Federal University, Ekaterinburg, Russia \\ *Corresponding author. E-mail: 79apa@mail.ru
}

This article examines psychological predictors of inhibition in educational environments as well as various aspects of pedagogical communication, including facilitation, which is aimed at enhancing educational effectiveness and developing students by means of using a particular communication style and the teacher's personality. The need to study inhibition (the deterioration of teacher-children interactions; the negation of a student's individuality; the inability to understand and accept students' viewpoints; teacher-provoked conflicts; and emotional callousness) is substantiated. The essence of psychological predictors as independent variables, changes in which lead to changes in other dependent variables, allowing the prediction of inhibition development, is explained.

The research objective was to identify psychological predictors of the development of inhibition in pedagogical communication.

An empirical study was conducted using standardized techniques for diagnosing communicative attitudes (V. Boyko), developing general communicative tolerance (V. Boyko), identifying aggressiveness (A. Asinger), identifying the level of empathy (V. Boyko), and identifying the degree of pedagogical inhibition (L. Polosova). The sample contained 375 teachers from Yekaterinburg educational institutions, with participant selection made using stratified sampling.

The teacher's personality features (a negative communicative attitude, low communicative tolerance and empathy, and higher levels of aggression) were shown to be key predictors of inhibition, which itself was found to depend on the length of teaching experience. At the beginning of one's professional teaching career, the level of inhibition is minimal. However, the level of inhibition reaches its maximum level after 5-10 years of teaching, and after 20 years, there is a sharp decrease in the level of inhibition.

The conclusion of this study stresses the importance of developing strategies to prevent and correct inhibition, which is especially essential for school teachers with 5-10 years of experience.

Keywords: pedagogical communication, inhibition, facilitation, educational environment, psychological predictors of development 


\section{Introduction}

The modern historical period of development, with its intensity, dynamism, contradictory trends and alternative viewpoints, differs sharply from previous periods, which are characterized by predictability and regularity, not in the quality or standard of living, but in its essence. Today, the availability of new cognitive technologies forms the basis for society's technological structure of an entirely different form and substance compared to all previous attempts (Sundiev, 2012).

This new technological structure is not associated with the production or processing of materials, but rather with changes in human beings. There now appear to be ways to transform personality, giving it desired properties and qualities. These methods are becoming increasingly effective, allowing the prospect of interfering with the production of human consciousness. According to I.A. Prokhorov, human consciousness will become as productive a force as science once was (Prokhorov, 2015).

In this context, the main objective of psychological science shifts from the simple diagnostics of different personality types to forecasting an individual's personality features and actions. Studying human potentialities, diagnosing the moral foundations for individual behavior in an accurate and timely fashion, and predicting success in activities and abilities to solve a wide range of non-standard tasks can be defined as some of the most important psychological objectives for the near future.

Consistent with this notion, changes in the Russian education system call for an entirely new professional organization; that is, they can be effective only within a new professionalizing socio-cultural paradigm. Its main distinctive feature is the change in the subject-subject relationship. There is a shift from meeting the need for highly qualified staff to supplying society with personnel trained by the new educational system, itself aimed at developing a creative mentality, professionalism and a person's moral maturity.

Under these circumstances, special attention should be paid to how pedagogical communication is organized.

\section{Theoretical framework}

At the core of pedagogical communication is the teacher's personality. Indeed, personality has a major impact on all aspects of communication, including perceptive, communicative, and interactive facets. The whole range of a teacher's personality features and communicative potential is uncovered in real interpersonal contacts (Rean, 1999).

Societal demand for highly professional educators who can create a favorable psychological atmosphere in the educational process and thus a foundation for children's emotional well-being forced scientists to take a fresh look at the issues of teachers' professional development (E.M. Bobrov, S.V. Vasilkovskaya, V.P. Savrasov and others) and professionally relevant features of a teacher's personality (F.N. Gonobolin, E.A. Grishin, Ya.L. Kolominsky, N.V. Kuzmina, A.A. Rean, and others).

In his works, A.A. Leontiev concluded that pedagogical communication takes place at all stages of one's upbringing and education. It first develops in infancy and 
early childhood, becoming more complex in its content and form in primary and secondary school lessons as well as in other types of educational work with students (A.A. Leontiev, 1996).

A.B. Orlov found that organized, pedagogically appropriate communication affects many aspects of students' personalities. These include their character, interests and abilities, in addition to their mental and moral development and personalities' emotional characteristics. The cognitive function of communication is also exemplified through the course of communication with students: teachers learn a lot about students and learn to analyze their psychological make-up (Orlov, 1983).

I.A. Zimnyaya believed that the effectiveness of pedagogical communication is inextricably linked with the teacher's personality and, as such, is determined by a range of factors. These factors include the teacher's personality features, which are important for communication; his or her communicative abilities and skills; the nature and style of pedagogical communication; and the effect of the nature of pedagogical communication on students' mental development. This author also highlighted such personality features as communicative attitudes, abilities, skills and knowledge, tolerance and empathy as being important for communication (Zimnyaya, 2000).

In her research, M.I. Lisina showed that everyday communication with children creates favorable opportunities to study them from a psycho-pedagogical viewpoint. It is crucial for teachers to understand the orientation of their teaching activities and specific methodologies. Systematic observation methods are considered to be the most effective and most accessible in pedagogical practice. When interacting and communicating with other people, a person meets a special need to contact another human. One of the effective ways to identify the nature of the need for communication is by analyzing the outcomes of this activity. The primary effect of communication is its ability to shape the other person's image and the subject's self-perception (Lisina, 1979).

In several studies from the 1960s and 1970s, the issue of mutual understanding between people came to be considered in psycho-pedagogical terms (A.A. Bodalev, G.F. Guseva, S.V. Kondratieva, V.N. Kunitsyna, A.A. Rusalinova, and M.P. Tihonova et al.), whereas previously it was mainly viewed as an object of general and socio-psychology (V.M. Bekhterev, A.P. Nechaev and I.A. Sikorski).

The results of these scientists' research show that a teacher must possess a whole set of qualities, the absence of which makes the implementation of a constructive relationship with a child under the conditions of pedagogical communication virtually impossible.

One of the general psychological preconditions for pedagogical communication is development of the teachers' optimum sociability, including its moral, psychological and pedagogical aspects. This will prevent any deviations, especially cold rationality, moralizing and formalism, in dealing with students, which weaken the pedagogical effect of communication and complicate the student-teacher relationship.

Pedagogical communication is the main way to implement the educational process. Its effectiveness is determined, above all, by the goals and values of communication, which should be accepted by all subjects of pedagogical communication. Such components as mutual recognition and understanding, information 
exchange, and interpersonal interaction are all integral parts of pedagogical communication.

Pedagogical communication leads to the appearance of various new psychological formations, both personal and interpersonal. These formations, called changes or phenomena, can be constructive (developing) or destructive (ruining). Inhibition is one of these changes inherent in pedagogical communication that has a negative effect on the subject of interactions in the educational process.

Pedagogical communication phenomena that occur in teachers' professional activity may exert various influences on children's mental development, as well as on the effectiveness of the process of discovering the students' personality. In recent years, psychology has turned to studying facilitation as a pedagogical communication phenomenon. In his concept of education, C. Rogers, who discovered this phenomenon in educational psychology, suggested using facilitation techniques. This concept shifts the emphasis from teaching to facilitating learning; towards promoting, assisting, encouraging and enhancing learners' development, giving them more freedom and responsibility (Rogers, 1994).

Rogers' followers emphasize that education should become a means of students' and teachers' personal growth. A teacher should act as a facilitator of communication - someone who encourages students' initiative and interpersonal interaction and promotes their mental development processes.

Teachers with a high level of facilitation are very critical of themselves, always try to uncover cause-and-effect relationships, work well in and for a team, establish and maintain contacts easily, perceive students as being important, are open in communication, cheerful, directed to the outside world of surrounding people and events, and have strong leadership qualities and business skills. Such teachers are sensitive to the needs and concerns of others, are generous, have a genuine interest in people, are emotionally responsive, are eager to maintain good relationships with people and are always ready to help others.

It should be noted that it is a pedagogical influence that allows students to notice the mismatch between 'I-real' and 'I-ideal', which is a necessary condition for development. Not only does pedagogical support carry out the function of protecting students from insecurity and the fear of failure in educational tasks but also helps in establishing their personal and real-world status.

With the myriad approaches to studying teachers' professionalism, psychological facts that impair interactions between teachers and children in the course of pedagogical communication remain insufficiently researched. One of these facts, in our opinion, is the inhibition phenomenon.

Inhibition is a complex integrative formation, the development of which is conditioned by teachers' negative individual psychological attributes; it is accompanied by the deterioration of pedagogical interactions in the course of pedagogical communication with children and negatively affects their emotional development.

In social psychology, there are few studies of inhibition, which is the opposite of the facilitation effect. Inhibition is characterized by the deterioration of interaction as well as suppression of the subjects of the communication and has an abiding negative impact on them. The phenomenon of inhibition, in our opinion, is inherent in pedagogical communication and must be studied more thoroughly. 
The phenomenon of inhibition manifests itself in tight and comprehensive control: the teacher resorts to a commanding tone and makes scathing remarks. Tactless remarks about some students, and unreasoned praise of others, are part of this pedagogical interaction. Such teachers set overall goals for work, indicate ways of performing tasks, and determine who will work with whom, while at the same time ignoring students' individualities and cognitive interests. Such an approach typically reduces students' motivation for any activity, as students do not know the purpose of their work, the function of each stage or what lies ahead (Pecherkina, 2013). It should also be noted that gradual regulation of student activity and tight control over them reveal the teacher's lack of belief in the students' positive potential. In the teacher's eyes, students have a low level of responsibility and deserve the toughest possible treatment, with any initiative seen as a manifestation of undesired self-will.

Relative to education, in general, and to the student-teacher relationship, in particular, inhibition acts as a deterrent to the effectiveness of learning activities, to their speed of completion and to the quality of their outcomes.

Based on both Russian and foreign authors' studies, one can assume that excitement is the main factor influencing inhibition. If a person is excited, the presence of appraising observers (teachers) will lead to increasingly less task fulfillment.

According to research by R. Zajonc, the presence of strangers improves performance on simple and familiar tasks and impairs it on complex and new tasks. The author became interested in how to interpret results that were initially contradictory. He used the principle of experimental psychology, in which excitement always strengthens a dominant reaction. Specifically, increased arousal improves the performance of simple tasks for which the most likely response is a correct decision. In complex tasks, however, where the answer is not obvious, such arousal leads to an incorrect response. In teaching, erroneous action is the most common dominant reaction (Zajonc R., Sales S., 1966).

R. Zajonc managed to experimentally demonstrate that the presence of other people strengthens excitement. This most important idea in his newly discovered concept leads to the conclusion that the mere presence of strangers impairs learning, as arousal increases and the person is often not responding properly. Such a presence, however, facilitates the performance of well-learned tasks.

Interestingly, K. Kottrel, V. Henchi, R. Glass, N. Klinger and others have shown that the presence of observers who were unable to evaluate the examinees' activity did not improve performance. An impeding or a positive effect was only present when the observers were able to evaluate the examinees' activity. Therefore, the mere presence of strangers is not a sufficient condition for inhibition. The observers, or participants in joint actions, should be seen as people who are able to assess the activities of the subjects. The ability to provide appraisal is an important component of the presence effect because based on our previous experience, each of us associates the positive or negative results of our activities with situations of appraisal. If we do our work well, we receive a favorable evaluation and obtain a positive result; if not, the appraisal is unfavorable and the result is negative (Mitrakhovitch, 2002).

Hence, inhibition in the educational process has a negative effect on its quality; it causes a decline in students' motivation for learning, as well as high levels of 
anxiety and aggression. As a result, predicting the development of inhibition in the communication process is an issue of current importance.

According to $\mathrm{Yu}$. V. Gromyko, prediction, at present, is closest to the established forms of scientific thinking and is virtually becoming the only doctrine by which to address the future. The external formation of an object, which moves under its own laws without changing the subject's thinking or consciousness, exists and lives inside the predictable whole, and this is the most common scientific methodology of working with the future (Gromyko, 1997).

I.V. Bestuzhev-Lada defined prediction as specialized scientific research whose subject is the prospects of phenomenon development (Bestuzhev-Lada, 1982).

When studying the role of prediction in the thinking process, A.V. Brushlinsky showed that it is the vision of the target that determines the economy, validity and accuracy of the solution; the activity's success most often depends on a person's ability to foresee their own or others' future behavior and to foresee the future development of events or situations (Brushlinsky, 1979).

According to L.A. Regush, human actions committed without trying to anticipate consequences, without taking into account the connections that may arise as a result of their intervention in biological or social processes, are, at best, useless and are also frequently harmful (Regush, 2003).

Various social institutions are interested in accurate diagnoses of individuals' make-up and abilities and in reliable forecasts about the effectiveness of their future activities and behavior. To achieve these objectives, predictive technologies should be used to identify and develop effective human resources. Predictors are a tool for obtaining these forecasts and a means for their expression.

The term 'predictor' (predict; to forecast) can have two different meanings, as well as both a broad and narrow context. Within its broad meaning, it is the individual's and his/her environment's initial attributes that allow the prediction of the same individual's other (desired) attributes. In its narrower meaning, the term 'predictor' acquires additional limitations that may be associated with the quantitative expression and evaluation of the forecast's statistical reliability. In regression analysis, used as a method of constructing a forecast, the term 'predictors' describes independent variables, changes in which can then lead to changes in other dependent variables (responses).

According to the nature of the effects being predicted, four basic types of predictors are distinguished: inter-level (in the personality structure), ontogenetic, professional and clinical.

Attributes or independent variables used for constructing predictors may be obtained from two main sources. The first source is a person's own characteristics. These can include a wide range of psychological and physiological qualities, from somatotype to communication style. The second source concerns the environmental factors of a person's existence: physical (space and objects) and social (family and wider circles of social interaction). The predictors' self-descriptiveness becomes higher when they combine the action of at least two or more factors (independent variables), that is, they have a complex nature.

The procedure for constructing complex predictors is used to identify individual predictive attributes and integrate them into complex predictors of psychological properties by means of multidimensional statistical analysis. In the course of 
statistical processing, both a person's attributes and environment, components that are potentially "significant" to the formation of the target attribute, can be included in the complex predictor.

Thus, the study of psychological predictors entails identification of the range of factors that determine the development of a psychological phenomenon and, additionally, an evaluation of these factors' influence on the effects being predicted (Maryutina, Trubnikov \& Ermolaev, 1998).

As a result, it becomes relevant to identify psychological predictors of inhibition development in pedagogical communication.

Based on a theoretical analysis of the body of literature (V.V. Boyko, I.A. Zimnyaya, E.F. Zeer, N.V. Kuzmina, A.K. Markova, L.M. Mitina, C. Rogers, C. Maslach, S. Jackson), we singled out the following psychological predictors of inhibition in the educational environment: communicative attitude, communicative tolerance, empathy and aggression. We then conducted an empirical study to identify the content of each predictor.

\section{Method}

The purpose of this research was to identify psychological predictors of inhibition development in pedagogical communication.

The research objective is to determine the factors that have a negative effect on children's emotional development in the course of pedagogical communication.

The theoretical and methodological basis for the research draws on the following:

- Theories of personality-oriented professional education (D.A. Belukhin, E.F. Zeer, I.A. Zimnya, A.A. Rean, L.A. Regush, V.V. Serikov, M.N. Snatkin, and I.S. Yakimanskaya);

- Personality-based and activity-based approaches (A.G. Asmolov, A.N. Leontiev, S.L. Rubinstein, and A.V. Petrovsky);

- Concepts of pedagogical activity and a teacher's personality (F.N Gonobolin, V.A. Krutetsky, N.V. Kuzmina, A.K. Markova, and V.A. Slastenin);

- Research into the influence of a teacher's professional activity on personality deformation development (S.P. Beznosov, V.V. Boyko, M.V. Borisova, N.E. Vodopyanova, N.V. Grishina, S. Jackson, E.F. Zeer, K. Maslach, L.M. Mitina, V.E. Orel, E.I. Rogov, T.I. Roginskaya, E.S. Starchenkova, and E.E. Symanyuk);

- Study of the issues of effective pedagogical communication (L.N. Bashlakova, I.A. Zimnyaya, Ya.L. Kolominsky, S.V. Kondrateva, E.A. Panko, L.M. Putyato, C. Rogers, and S.S. Harin),

- Theory of communication and activity unity (G.M. Andreeva, A.N. Leontiev, B.F. Lomov, and D.B. Elkonin).

\section{Hypothesis}

The teacher's individual psychological characteristics, such as negative communicative attitude, low level of communicative tolerance, low empathy and high aggression level, serve as internal predictors of inhibition development in teachers. 


\section{Research methods}

- The technique for diagnosing teachers' communicative attitudes (V.V. Boyko) identified the indicators of a negative communicative attitude, namely, implicit violence, open violence, justified negativism, grumbling, and negative communicative experience.

- Assessing the level of teachers' general communicative tolerance (V.V. Boyko) included examining the following domains: rejection or misunderstanding another person's individuality; using oneself as a reference when evaluating other people's behavior and way of thinking; self-righteousness or conservatism in evaluating other people; inability to hide or smooth unpleasant feelings when dealing with uncommunicative partners; desire to change partners; desire to adjust partners to oneself and make them "convenient"; inability to forgive others' mistakes, awkwardness, confusion, or unintended trouble caused to partners; intolerance to physical or mental discomfort caused by other people; and inability to adapt to other people's characteristics, habits and desires.

- The technique for assessing the level of aggression (A. Assinger) comprised a single scale to identify the degree of aggressiveness manifestation - that is, moderate, excessive or medium.

- The technique for assessing the capacity for empathy (V.V. Boyko) included the following scales: rational channel of empathy, emotional channel of empathy, intuitive channel of empathy, attitudes encouraging empathy, penetrating power in empathy, identification in empathy, and one's general level of empathy;

- The questionnaire used to assess the degree of pedagogical inhibition (L.B. Polosova) comprised a single scale to identify the extent to which manifestation was being inhibited - that is, low, medium or high.

\section{Research stages}

The study of psychological predictors of inhibition in the course of interactions between teachers and children in pedagogical communication was conducted from 2010 to 2014 and included three stages.

The first stage (2010) was devoted to psychological and pedagogical literature analysis. The scientific concept of inhibition was defined and its constituent parts determined. We then formed the conceptual framework for the research.

During the second stage (2011), the research subject - psychological predictors of inhibition - was determined. Psychodiagnostic methodologies were then developed, selected and adapted.

The third stage (2012-2014) was devoted to studying psychological predictors of teachers' inhibition and to analyzing and summarizing the research results.

To determine the differences in the manifestation of individual psychological characteristics in teachers with varying levels of inhibition, a comparative analysis using the Mann-Whitney U test was carried out.

The study was conducted individually and anonymously. Each teacher received a packet of forms with questionnaires. 


\section{Results and discussion}

Our sample contained 375 teachers of different subjects from various secondary educational institutions in Yekaterinburg, with participant selection made using stratified sampling. Eight schools from different administrative districts of Yekaterinburg were randomly selected, and all of the teachers within each school, without exception, were subsequently examined. Since the vast majority of the teachers were women, the conclusions obtained may not be generalizable to males.

The age distribution of the sample was as follows: $20 \%$ were under 30 years, $30 \%$ were aged 30 to $40,38 \%$ were 40 to 50 years old, and $12 \%$ were over 50 .

The distribution of the participants according to their teaching experience was as follows: up to 3 years $-12 \%$; 3 to 5 years $-37 \%$; 5 to 10 years $-25 \%$; 10 to 20 years $-21 \%$; and 20 to 30 years $-5 \%$.

Each participant had earned a degree in pedagogy, with 78\% holding a university degree and $12 \%$ a vocational training degree.

Additionally, $33.9 \%$ of the teachers were found to have a markedly negative communicative attitude. Teachers with a negative communicative attitude had high scores on two related domains: covert severity (62.5\% of teachers) and reasonable negativity ( $47.5 \%$ of teachers). Overt severity was observed in $25.4 \%$ of the teachers, grumbling in $25 \%$, and negative experience of communication in $16 \%$.

Teachers with a markedly negative communicative attitude are disposed to hostility, wary of dealing with people, prone to make negative conclusions about people and reluctant to respond to others' concerns. Moreover, they have an inflated self-esteem and reduced self-criticism. They can be aggressive and inconsistent in their statements, although they tend not to identify these qualities in themselves. As a rule, they prefer not to hide and not to soften their negative estimations and experiences. These characteristics can erode the pedagogical communication process and create a negative emotional background and thus threaten the nurturing atmosphere of the educational environment.

Questionnaires also showed that $30.5 \%$ of the participants had low levels of communicative tolerance.

Teachers with low communicative tolerance scored highly in the following areas: rejection and lack of understanding of a person's identity, 37.5\% of participants; categorical/unqualified and conservative judgements about people, $40 \%$; inability to hide unpleasant emotions when encountering uncommunicative partners, 50\%; tendency to demand flexibility in their partners in terms of personal relationships, $37.5 \%$; and an inability to adapt to one's partner. $37.5 \%$.

Such components as using oneself as a benchmark for evaluating others were found in $25 \%$ of the teachers; a desire to change and re-educate the partner in $20 \%$; a lack of ability to forgive mistakes or gaffes in $20 \%$; and an un willingness to tolerate physical or mental discomfort from the partner in $20 \%$.

A low level of communicative tolerance determines behavior and causes lasting maladjustment to the communication partner. Teachers with low levels of communicative tolerance are unable to accept students' identity in pedagogical communication due to a mismatch of personality substructures, thus denying the students the right to individuality. They also judge children relative to their own habits, at- 
titudes and moods and may show unmanageable negative reactions in response to antisocial qualities in children. Such teachers try to re-educate students in a rough or a soft manner, seeking to regulate their actions and make children behave like they themselves. These teachers insist that children adopt their viewpoints, evaluate students relative to their own circumstances, and so on. In cases where a child is looking for sympathy, the teacher does not notice, gets irritated or condemns them.

High levels of aggression were found in $62 \%$ of the teachers. This suggests that they are prone to outbreaks of aggression, which are more destructive than constructive. They are also prone to ill-considered actions and fierce debates, may treat people disparagingly, and by their own behavior, provoke situations of conflict that could be avoided. In other words, it can be assumed that a high level of aggression has a damaging effect on students' personality structures.

One's level of empathy characterizes the person's focus of attention, perception and thinking on understanding another person's nature, condition, problems and behavior. As such, $67 \%$ of the teachers were found to have low levels of empathy. This characteristic manifests itself in the inability to understand another person's inner world and predict the interlocutor's behavior; in an avoidance of personal contacts; and in the development of a limited range of emotional responsiveness and empathic perception.

The next stage of this research was identifying the degree of inhibition in teachers using the questionnaire developed by Polosova L.B.

The majority of the teachers were found to have medium and high levels of inhibition.

Between-group comparisons of communicative attitude indicators showed that the compared groups exhibited statistically significant differences in the degree of a number of variables, specifically, covert severity $(z=164.10 ; p=0.04)$, overt severity $(\mathrm{z}=171.0 ; \mathrm{p}=0.04)$, reasonable negativity $(\mathrm{z}=157.50 ; \mathrm{p}=0.02)$, and negative experience of communication $(\mathrm{z}=116.5 ; \mathrm{p}=0.04)$.

Teachers with high levels of inhibition (42\%) also had higher levels of covert and overt severity towards others, demonstrated reasonable negativity in judgments about people, and received high scores on measures that confirmed a negative personal experience in communicating with others. Their judgements contain, in a disguised, subdued or sometimes overt manner, hostility, wariness in dealing with many partners, negative conclusions about people, and an unwillingness to sympathize with other people's problems. They are also characterized by poor control over their own emotions and behavior.

The participants with low levels of inhibition (15\%) demonstrated low scores in all of the components of communicative attitude.

The analysis of differences between teachers with high and low levels of inhibition revealed significant dissimilarities in the magnitude of components to communicative tolerance. Specifically, analyses showed a rejection or a lack of understanding of human individuality $(\mathrm{z}=169.0 ; \mathrm{p}=0.04)$, rigidity or conservatism in their estimations of other people $(z=134.0 ; p=0.04)$, inability to hide or sooth unpleasant feelings when encountering antisocial qualities in partners $(\mathrm{z}=180$, $\mathrm{p}=0.03)$, desire to make their partner adapt to themselves $(\mathrm{z}=100.0, \mathrm{p}=0.02)$, and 
inability to adjust to their partners $(z=122.0 ; p=0.04)$. Reliable differences in aggression indicators were also found $(z=112.5 ; p=0.02)$.

Teachers with high levels of inhibition have low scores on empathy, high scores on aggression, a low degree of communicative tolerance, and demonstrate a marked negative communicative attitude in pedagogical communication.

Teachers with low levels of inhibition have higher scores on empathy, low scores on aggression, an adequate degree of general communicative tolerance, and show appropriate communicative attitudes in pedagogical communication.

This study also revealed a correlation between the degree of inhibition and amount of teaching experience.

The highest degrees of inhibition were observed in respondents with 5 to 10 years of experience (Table 1).

Table 1. Degree of inhibition in groups with different teaching experience, \%

\begin{tabular}{lcccc}
\hline Teaching experience & up to 5 years & $5-10$ years & $10-20$ years & $20-30$ years \\
\hline High level of inhibition & 0 & 67 & 40 & 20 \\
\hline
\end{tabular}

Teachers with no more than 5 years of teaching experience tend to search for optimum behaviors and better ways in which to perform professional activities. As a result, they demonstrate a readiness for possible failure, and the lack of professional status renders them less afraid to make mistakes, as unsuccessful professional activity is normal at this stage. Therefore, strong manifestations of inhibition in this experience-level group were not observed.

The degree of inhibition increases dramatically in teachers with 5 to 10 years of experience and was observed in $67 \%$ of the subjects. This appears to reflect a connection with the fact that this stage is characterized by gaining experience and elevating the employees' status, which can result in increased dissatisfaction with the activities performed and positions held. At this juncture, strategies for professional development and surmounting professional difficulties are not yet established; this results in the release of psychological tension in pedagogical communication at a cost to the teacher-dependent students.

The results obtained in the group with 10 to 20 years of experience show a dramatic decrease in inhibition (only $40 \%$ of the respondents showed a high degree of inhibition). This may be due to the respondents' age characteristics and to their choosing suppressive behavior strategies. People at this stage actively change their lives and are searching for more fulfilling life strategies.

The results for the group of teachers with 20 to 30 years of experience fit the overall downward trend of the degree of inhibition, again depending on the extent of teaching experience. Only 20\% of those respondents showed high levels of inhibition. This may be due to the achievement of an increased professional status and its importance for teachers, as well as to the development of constructive forms of pedagogical communication and the greater ability to overcome professional difficulties and conflicts.

The results of this empirical research reveal the essence of the concept of inhibition not only as a suppressor (considered as such by R.R. Miller, M.A. Laborda, 
C.W. Polackand others) but also in the context of pedagogical communication. This approach is new to the science of psychology, both foreign and Russian.

Researchers have extensively studied the effects of facilitation on educational process. E.F. Zeer is the author of the concept of facilitation in teaching (Zeer, 2010). E.G. Vrublevskaya and O.I. Dimova have studied facilitating communication as a form of pedagogical interaction (Vrublevskaya, 2001; Dimova, 2002). In addition, I.V. Zhizhina and O.N. Shakhmatova considered issues with regard to developing facilitation skills in teachers (Zhizhina, 2000; Shakhmatova, 2006).

Rogers explored the characteristics of personality, activities, communication and creativity in teachers who are capable of facilitating learning (Rogers, 1994). Tassou noted that the teacher must create an environment of psychological safety for the student, where there is no external assessment. He emphasized the fact that the teacher-facilitator contributes to the formation of learners' creativity and selfexpression (Tassou, 2009).

Thus, the study of psychological predictors of inhibition in the context of pedagogical activity is new to the science of psychology and extends the idea of the teacher's role in developing teacher-learner interactions.

\section{Conclusion}

The results obtained suggest the following conclusions:

1. The following psychological predictors are associated with increased inhibition in teachers: a negative communicative attitude, low degree of communicative tolerance, high levels of aggression, and low levels of empathy.

These qualities manifest in difficulties connecting interpersonally (with students, parents, colleagues and administrators of educational institutions) and in achieving mutual understanding with others. They also result in hostility, wariness and the inability to accept a student's individuality in pedagogical communication, as well as in attempts to re-educate them and a desire to regulate their actions. Such teachers insist that students adopt the teacher's point of view, are prone to ill-considered actions and fierce discussions, disparage students and often provoke conflicts that could be easily avoided. These teachers do not seek to understand the inner world of any other person, are unable to predict the interlocutor's behavior, avoid personal contacts, and demonstrate emotional callousness.

2. The degree of inhibition and its manifestation were found to correlate with the amount of teaching experience. At the beginning of one's professional life, the degree of inhibition is minimal. Later, it reaches its maximum in teachers with 5 to 10 years of experience. After 20 years or more of teaching experience, inhibition decreases sharply.

This degree of inhibition is conditioned by the lack of constructive forms of pedagogical communication and ways of dealing with arising conflicts, as well as by the lack of established strategies for professional development and the means of overcoming professional difficulties. As a result, teachers release their psychological tension on students who are dependent on them.

The results substantiate the need for developing technologies for preventing and correcting inhibition in teachers with 5 to 10 years of experience to create a more psychologically favorable atmosphere in educational institutions. 


\section{Acknowledgements}

The authors express their gratitude to the teachers working in Yekaterinburg schools who agreed to take part in the research.

\section{References}

Bestuzhev-Lada, I.V. (1982). Rabochaya kniga po prognozirovaniyu [Workbook of forecasting]. Moscow: Mysl.

Brushlinsky, A.V. (1979). Myshleniye i prognozirovaniye. [Thinking and forecasting]. Moscow: Mysl.

Dimova, O.I. (2002). Pedagogicheskiye usloviya razvitiya sposobnosti $k$ fasilitiruyushchemu vzaimodeystviyu u budushchikh uchiteley. [Pedagogical conditions for developing the skills of facilitating interaction in future teachers] (Unpublished doctoral dissertation). Komsomolsk-na-Amure State Pedagogical University: Khabarovsk, Russia.

Gromyko Yu.V. (1997). Proyektnoye soznaniye: Rukovodstvo po programmirovaniyu i proyektirovaniyu v obrazovanii dlya sistem strategicheskogo upravleniya [Project mentality: A guide to programming and design in education for strategic management systems]. Moscow: Institut uchebnika Paideia.

Leontiev, A.A. (1996). Pedagogicheskoye obshcheniye. [Pedagogical communication]. Moscow.

Lisina, M.I., \& Galiguzova L. N. (1979). Izucheniye stanovleniya potrebnosti v obshchenii so vzroslymi i sverstnikami detey rannego vozrasta [The study of the development of the need for communication with adults and children of their age in infants]. In Psihologo-pedagogicheskie problemy obshhenija [Psychological and pedagogical issues in communication] M.I. Lisina (Ed.). (pp. 60-79). Moscow.

Maryutina, T.M., Ermolaev, O.Yu., \& Trubnikov V.I. (1998). O prirode psikhologicheskikh prediktorov. [On the nature of psychological predictors]. Psikhologicheskaya nauka i obrazovaniye [Psychological Science and Education], 1, 22-24.

Mitrakhovitch, O.A. (2002). Osobennosti otsenochnoy deyatel'nosti uchitelya: Vchera, segodnya, zavtra [Pecularities of a teacher's assessment activity: Yesterday, today, tomorrow]. Psikhologia [Psychology], 3, 20-28.

Orlov, A.B. (1983). Sklonnost i professiya [Inclination and profession]. Moscow: Znanie.

Pecherkina, A.A. (2013). Psikhologicheskiye determinanty psikhologicheskogo nasiliya v obrazovatelnoy srede [Psychological determinants of psychological violence in educational sphere]. Pedagogicheskoye obrazovaniye v Rossii [Pedagogical Education in Russia], 5, 122125.

Rean, A.A. (1999). Sotsialno-pedagogicheskaya psikhologiya [Socio-pedagogical psychology]. St. Petersburg: Piter.

Regush, L.A. (2003). Psikhologiya prognozirovaniya: Uspekhi v poznanii budushchego [Psychology of prediction: Success in forecasting the future]. St. Petersburg: Rech.

Rogers, C.R. (1994). Freedom to Learn (3rd ed.). New York: Pearson. (Original work published 1969)

Rogers, C. (1995). On Becoming a Person: A Therapist's View of Psychotherapy. New York: Mariner Books. (Original work published 1961)

Shakhmatova, O.N. (2006). Pedagogicheskaya fasilitatsiya: Osobennosti formirovaniya i razvitiya [Pedagogical facilitation: Specifics of the development]. Nauchnyye issledovaniya $v$ obrazovanii [Scientific Research in Education], 3, 118-125. 
Sundiev, I. Yu. (2012). Kognitivnyye tekhnologii: temnaya storona progressa [Cognitive technologies: the dark side of progress]. Nauchnyy portal MVD Rossii [Scientific Portal of Russian Internal Affairs Ministry], 1, 79-84.

Tassoul, M. (2009). Creative facilitation. Delft, Netherlands: VSSD.

Vrublevskaya, Ye. G. (2001). Razvitiye sposobnosti pedagogov $k$ fasilitiruyushchemu obshcheniyu [Developing teachers' skills in facilitating communication]. Khabarovsk, Russia: Kolorit.

Zajonc, R. B., \& Sales, S. M. (1966). Social facilitation of dominant and subordinate responses. Journal of Experimental Social Psychology, 2(2), 160-168. doi: 10.1016/0022-1031(66) $90077-1$

Zeer, E.F. (2010). Lichnostno-razvivayushiye tekhnologii nachalnogo professionalnogo obrazovaniya [Personal development technologies in professional education]. Moscow: Izdatelskiy tsentr "Akademiya".

Zhizhina, I.V. (2000). Psikhologicheskiye osobennosti razvitiya fasilitatsii pedagoga [Psychological features of facilitation development in teachers]. (Unpublished doctoral disseration). Ural State Professional-Pedagogical University: Ekaterinburg, Russia.

Zimnaya, I.A. (2000). Pedagogicheskaya psikhologiya [Pedagogical psychology]. Moscow: Logos.

Original manuscript received October 12, 2015

Revised manuscript accepted May 16, 2016

First published online September 30, 2016 